karakteriseren als een etnografische studie. Jammer genoeg wordt de werkwijze slechts summier aangestipt en nauwelijks beargumenteerd. De informatie uit de gesprekken lijkt achteraf te zijn gestructureerd, waardoor de hoofdstukken soms wat lijken samengeraapt. Met name bij een veelheid aan details over popgroepen, eetgelegenheden, kledingmerken en favoriete discotheken dringt zich de vraag op wat het nut is van deze informatie. In het nawoord worden de grote lijnen uit de interviews gehaald en gerelateerd aan het doel van de studie. In de hoofdstukken zelf mis ik echter een duidelijke leiddraad die het lezen van de brei aan de details wat meer kader geeft. Anderzijds geven deze (voor mij) wat onsamenhangende details wel aan wat voor de jongens belangrijk is.

Dit boek is het verslag van invoelend veldwerk en een unieke samenwerking met de jongens bij het schrijven van dit boek, met respect voor wat zij wel en niet wilden vermelden. Dat maakt het boek exemplarisch erg goed. Wellicht is dit een waardevol boek voor (beginnende) culturele jongerenwerkers en autochtone Nederlanders met bepaalde vooroordelen. Ook voor onderzoekers op het terrein van etnische identiteit, multiculturele verschillen en integratie vormt deze studie een goed vertrekpunt.

\title{
Repliek op Arenda Kieviet
}

\section{Louis Boumans, Margreet Dorleijn en Hester Dibbits}

Laten we, om te beginnen, zeggen dat we ingenomen zijn met de aandacht voor dit boek in KWALON en met de overwegend positieve bespreking van Kieviet.

Omdat Jongens uit de Buurt $(=J u d B)$ vooral gericht is op niet-wetenschappelijk publiek, bevat het weinig informatie over de gevolgde werkwijze. Misschien kunnen we daarvan iets goedmaken in deze repliek.

Eerst hebben we drie dialogen opgenomen met steeds twee van de jongens, zonder tussenkomst van de onderzoekers. De jongens kregen alleen een papier met zes stellingen mee over alledaagse cultuur, etnische identiteit en het leven in de wijk. Deze opzet had deels te maken met andere projecten binnen het algemene onderzoeksprogramma. Vervolgens hebben we in overleg met de jongens de thema's van de hoofdstukken vastgesteld en met ieder een open interview gehouden aan de hand van een topiclijst op basis van deze thema's. Ook deze interviews zijn opgenomen, evenals de interviews met vier medewerkers van een jongerencentrum waar de vrienden regelmatig kwamen. Ten slotte hebben wij gezamenlijke gesprekken gevoerd met de jongens, in wisselende combinaties. Die laatste gesprekken hadden het spontaanste verloop.

Reeds bij aanvang van het project was afgesproken dat het boek tot stand zou komen in nauwe samenwerking met de vriendengroep. Dit is ook gebeurd. Alle hoofdstukken zijn voorgelegd aan de jongens, en enkele passages zijn op hun verzoek aangepast of geschrapt. In die zin is $J u d B$ niet alleen een boek over, maar ook een boek van migrantenzonen in de grote stad. 
Voor alle betrokkenen was de samenwerking een experiment. Voor ons (twee taalkundigen en een etnologe) was onder meer de verwachting van belang dat de samenwerking de sociale afstand tussen onderzoeker en informant zou overbruggen. Voor de jongens was met name de overweging van belang dat hen een mogelijkheid werd geboden om hun ideeën uit te dragen. De nauwe samenwerking bracht natuurlijk ook beperkingen met zich mee, net als de afspraak dat de jongens met naam en foto in het boek terecht zouden komen. De gevoerde discussies over de teksten zouden een interessant uitgangspunt vormen voor een wetenschappelijk artikel. Vraag is echter of de jongens akkoord zouden gaan met een dergelijk artikel, aangezien hun anonimiteit niet te garanderen valt.

Een van de voornaamste kritiekpunten van Kieviet betreft de veelheid aan details. Deels komt dit voort uit onze keuze om niet de nadruk te leggen op attitudes, maar op concrete gedragingen. Wij wilden de dynamiek (en de grenzen daarvan) laten zien in de talige en culturele repertoires van de groep als geheel en van alle acht jongens afzonderlijk.

Algemene, abstracte termen als casual kleding en mellow muziek zijn dan ontoereikend. Daarnaast hebben de details een functie in de communicatie tussen de geportretteerden en de lezer. Wanneer men de muziekgroepen, kledingmerken of locaties uit het leven van de jongens herkent, kan men zich eerder met hen identificeren.

Dit alles neemt niet weg dat de informatie op sommige punten wellicht korter had gekund of overzichtelijker gepresenteerd. Het laatste woord komt toe aan de lezer. Kieviet suggereert als potentieel lezerspubliek jongerenwerkers en bevooroordeelde Nederlanders. Uit reacties in het veld maken we op dat er nog een belangrijk publiek is, namelijk (allochtone) jongeren die in een vergelijkbare situatie verkeren als de jongens uit het boek.

\title{
Wanneer je het de leerlingen vraagt...
}

\author{
Jacob van der Wel
}

Jorien Meerdink, m.m.v. Margot Hameetman, Vraag het aan de leerlingen! Een verkennend onderzoek naar leerlingenparticipatie en de brede school in het voortgezet onderwijs. Amsterdam: SWP, 200I, II2 p. ISBN 906665442 2. € I2,-.

\section{Inleiding}

Voor sommigen die, zoals ik, in de jaren zeventig naar de middelbare school zijn gegaan, is leerlingenparticipatie een lost cause. Geïnspireerd door oudere broers en zussen op de universiteit en door een progressieve maatschappijvisie kende iedere school wel haar actieve leerlingen die de misstanden op school aan de kaak wilden stellen; leerlingen die het recht meenden te hebben om zelf hun schoolloopbaan vorm te geven of, minimaal, daar meer grip op te krijgen. Helaas dacht de conrector daar anders over, misschien ook wel typisch voor het onderwijs: 'Jij kan die verantwoordelijkheid misschien wel aan, maar de meeste andere leerlingen niet en aangezien we hier op school maar één lijn kunnen trekken, betekent dit dat die 